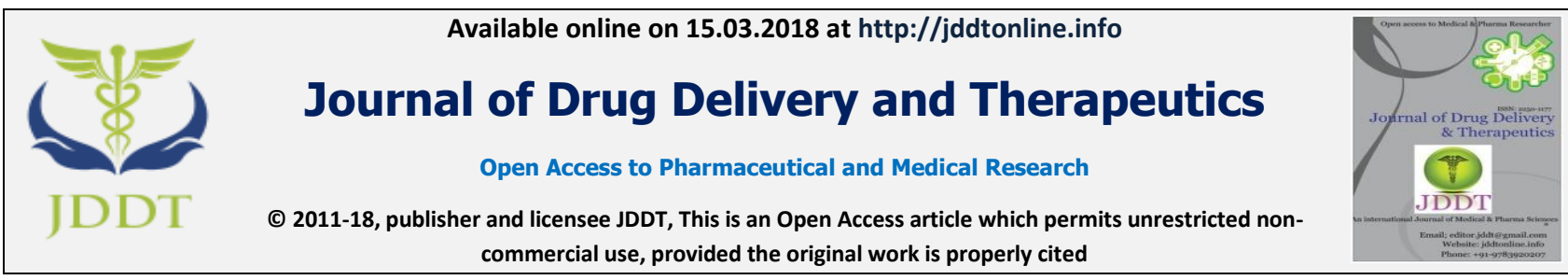

Open $\odot$ Access

Research Article

\title{
EVALUATION OF PHYSICOCHEMICAL STANDARDIZATION PARAMETERS OF SOLENA AMPLEXICAULIS LEAF
}

\author{
Agarwal Kshitij* and Jain Anurekha \\ Jyoti Vidyapeeth Women's University, Jaipur, Rajasthan, India
}

\begin{abstract}
Solena amplexicaulis, commonly called as the creeping cucumber, belongs to the family Cucurbitaceae. Traditional it is used as astringent, appetizer, carminative, cardiotonic, digestive, diuretic, expectorant, invigorating, purgative and stimulant. This plant also has antioxidant antidiabetic and antibacterial action. The leaves showed potent anti-inflammatory activity. The present study was carried out to establish physico-chemical parameters along with preliminary phytochemical screening of petroleum ether, chloroform, methanolic and aqueous extracts of Solena amplexicaulis leaf. Preliminary phytochemical screening of various extracts revealed the presence of carbohydrate, alkaloids, flavonoids, sterols, phenolic \& tannins compounds. The physico-chemical parameters such as total, water soluble, acid insoluble and sulphated ash $(2.2,1.9,1.17$ and 1.3\%w/w respectively) and loss on drying $(10.0 \% \mathrm{w} / \mathrm{w})$, extractive values foaming and swelling index were studied. These studies will be helpful in developing standards for quality, purity and sample identification of this plant.
\end{abstract}

Keyword: Standardization, Solena amplexicaulis, physicochemical and phytochemical.

Article Info: Received 09 Jan, 2018; Review Completed 18 Feb, 2018; Accepted 21 Feb, 2018; Available online 15 March, 2018

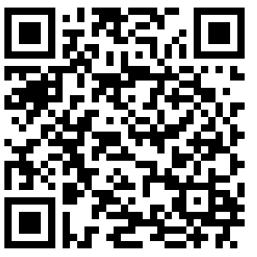

Cite this article as:

Agarwal K, Jain A, Evaluation of physicochemical standardization parameters of Solena amplexicaulis leaf , Journal of Drug Delivery and Therapeutics. 2018; 8(2):29-31

DOI: http://dx.doi.org/10.22270/jddt.v8i2.1661

*Address for Correspondence Kshitij Agarwal, Jyoti Vidyapeeth Women's University, Jaipur, Raj., India

\section{INTRODUCTION}

Solena amplexicaulis is a scandent dioecious perennial herb with several spindle-shaped tuberous roots which are $1.5-2 \mathrm{~cm}$ in diameter and with slender branched furrowed, stems bearing simple tendrils; Leaf-stalk slender, 4-10 mm, finely velvet-hairy at first, becoming hairless after some time. Leaf blades are very variable may be polymorphous, ovate, suborbicular, oblong or narrowly lanceolate in shape, 3-5 angled or lobed, lobes are lathery, usually cordate at base, reticulately veined beneath, margins remotety denticulate, oblong-lance shaped, lance shaped, or triangular, 8-12 × $1-5 \mathrm{~cm}$, below densely bristly or almost hairless, above densely bristly or scabrous, base heart-shaped, margin entire or toothed, tip blunt or tapering. Flowers are small and yellow in color. Male flowers are umbellate or subumbellate, flower-cluster-stalk is very short, apically with 10-20-flowered. Flower-stalks are $2-8 \mathrm{~mm}$ in length, calyx tube about $3-5 \mathrm{~mm}$ in length and about 3 $\mathrm{mm}$ in diameter. Flowers are yellow or yellow-white in colour, petals are triangular in shape, 1-1.5 mm in size, tip of petals are blunt or pointed, filaments are threadlike, about $3 \mathrm{~mm}$ in length. Female flowers are usually solitary, flower-stalk is about $2-10 \mathrm{~mm}$ in lenght, finely velvet-hairy, calyx and flower of female flower is same as male flowers. Ovary is ovoid in shape, 2.5-3.5 $\times 2-3$ $\mathrm{mm}$ in diameter, stigmas are 3 in number. Fruit is redbrown in colour, broadly ovoid, oblong, or nearly spherical in shape, $2-6 \times 2-5 \mathrm{~cm}$ in size. Seeds graywhite or gray-brown in colour, nearly round or ovate in shape, 5-7 $\times 5-6.5 \mathrm{~mm}$ in size and smooth or slightly tuberculate. The flowering month for the plant is from May to August. For the standardization and quality assurance purpose, we make an attempt for the standardization of Solena amplexicaulis leaf by carrying out its pharmacognostical studies ${ }^{1-5}$. 


\section{MATERIALS AND METHODS}

Plant Material: The leaves of Solena amplexicaulis were collected from the hills of Chamoli, Uttarakhand in the month of August 2017 and authenticated by Dr. Rajeev Soni, Botanist and Head, Nirmal Institute of Medicinal and Aromatic Plant Studies, Indore, M.P. The plant material $(1 \mathrm{~kg})$ was air-dried at room temperature $\left(30-40^{\circ} \mathrm{C}\right)$ and then powdered to pass through a sieve of $1 \mathrm{~mm}$ and further subjected to various studies.

Chemical and Reagent: All the chemical and solvents used for the study were of analytical grade and all methods were taken from official methods.

Physicochemical Parameters: The physicochemical parameters such as percentage of total ash, acidinsoluble, water soluble and sulphated ash, loss on drying, extractive values, foaming index, swelling index, crude fibre and heavy metal were determined according to official methods for quality control of medicinal plant $^{6-11}$.

Preliminary Phytochemical Screening: The preliminary photochemical screening was carried out on extracts obtained after successively extraction with petroleum ether, chloroform, methanol and aqueous solvents. The dried extracts were treated for the presence or absence of phytoconstistuents ${ }^{12-14}$.

\section{RESULTS AND DISSCUSSIONS}

Physico-chemical Parameters: The various parameters such as total ash, acid insoluble ash, water soluble ash, sulphated ash, loss on drying were established and shown in Table 1. The extractive values by successive extraction method and colour change of extracts, in visible and UV light are summarized in Table 2.

Table 1: Ash values and loss on drying of Solena amplexicaulis leaf

\begin{tabular}{|l|l|c|} 
S. $\mathbf{N}$. & $\begin{array}{l}\text { Evaluation } \\
\text { parameter }\end{array}$ & Value $(\% \mathbf{w} / \mathbf{w})$ \\
\hline 1 & Total ash & $2.2 \pm 0.453$ \\
\hline 2 & Water-soluble ash & $1.9 \pm 0.068$ \\
\hline 3 & Acid-insoluble ash & $1.17 \pm 0.427$ \\
\hline 4 & Sulphated ash & $1.3 \pm 0.211$ \\
5 & Loss on Dying & $10.0 \pm 0.014$ \\
\hline
\end{tabular}

Value: $\%$ w/w \pm S.E.M.; $n=3$

Table 2: Extractive value (percentage yield) and colour of Solena amplexicaulis leaf extracts

\begin{tabular}{|l|l|l|l|l|}
\hline \multirow{2}{*}{ Solvents used } & \multirow{2}{*}{ Percentage yield } & \multicolumn{3}{|c|}{ Colour of extract } \\
\cline { 3 - 5 } & & Visible light & $\mathbf{2 5 4} \mathbf{~ n m}$ & $\mathbf{3 6 5} \mathbf{~ n m}$ \\
\hline Petroleum ether & $1.2 \pm 0.04$ & Yellowish & Greenish & Greenish \\
\hline Chloroform & $2.9 \pm 0.03$ & Yellowish Brown & Brownish & Yellowish black \\
\hline Methanol & $5.75 \pm 0.02$ & Greenish Brown & Brownish Black & Black \\
\hline Water & $6.54 \pm 0.08$ & Brownish Green & Brownish Black & Black \\
\hline
\end{tabular}

Quantitative studies: The other quantitative studies for foaming index and swelling index were performed. The swelling index of tasted samples was found to be less than 1 and the foaming index of tested samples was found to be less than 100 .

Crude and heavy metal analysis: Heavy metals in Solena amplexicaulis leaf samples were analyzed. The percentage crude fiber and the presence of heavy metal are tabulated in Table 3.

Table 3: Concentration of heavy metals and percentage of crude fibre in Solena amplexicaulis leaf

\begin{tabular}{|l|c|}
\hline Heavy metal & Concentration (ppm) \\
Arsenic & 0.0254 \\
\hline Iron & 0.1939 \\
\hline Copper & 0.0147 \\
\hline Zinc & 0.0336 \\
\hline Lead & 0.0057 \\
\hline Cadmium & 0.0009 \\
\hline Mercury & 0.0217 \\
Cobalt & 0.0131 \\
\hline Crude fibre $(\%)$ & $7.3 \%$ \\
\hline
\end{tabular}

Preliminary phytochemical studies: The preliminary phytochemical screening of Solena amplexicaulis leaf extracts were performed for various phytoconstituents. It revealed the presence of different phytoconstituents, like carbohydrates, alkaloids, glycoside, phenolic \& tannins, flavonoid, protein \& amino acid and sterols in different extracts. Results are shown in Table 4.

\section{CONCLUSION}

From ancient time, plants having specific therapeutic property, desirable action, easy availability with less toxicity. The scientists from past few decades are keen and sincere to evaluate many ethno medicinally used plants. The leaf of Solena amplexicaulis is still traditionally used in treatment of various disorders by many populations. The physicochemical evaluation of this plant gives the idea about identification and standardization of the plant. It is also important in long term study of plant to evaluate the medicinal and therapeutic action of this plant. 
Table 4: Preliminary phytochemical screening of Solena amplexicaulis leaf extracts

\begin{tabular}{|c|c|c|c|c|}
\hline Test & Pet. Ether extract & Chloroform extract & Methanol extract & Aqueous extract \\
\hline \multicolumn{5}{|l|}{ Carbohydrate } \\
\hline Molish'reagent & - & - & + & + \\
\hline Fehling solution & - & - & + & + \\
\hline Benedict solution & - & - & + & + \\
\hline \multicolumn{5}{|l|}{ Alkaloid } \\
\hline Mayer'reagent & + & + & - & - \\
\hline Dragondroff'reagent & + & + & + & - \\
\hline Hager' reagant & + & + & - & - \\
\hline \multicolumn{5}{|l|}{ Glycoside } \\
\hline Killer Killani & - & - & + & - \\
\hline Sod. nitroprusside & - & - & - & - \\
\hline \multicolumn{5}{|l|}{ Phenolic and Tannin } \\
\hline $\mathrm{FeCl}_{3}$ Solution & - & + & + & + \\
\hline Lead acetate solution & - & + & + & + \\
\hline \multicolumn{5}{|l|}{ Sterols } \\
\hline Salkowski reaction & - & + & + & - \\
\hline Hesse's reaction & - & + & + & - \\
\hline \multicolumn{5}{|l|}{ Flavonoid } \\
\hline Ammonia solution & - & + & + & + \\
\hline Shinoda test & - & + & +1 & + \\
\hline \multicolumn{5}{|l|}{ Saponin } \\
\hline Foam test & - & - & - & - \\
\hline \multicolumn{5}{|c|}{ Protein and Amino acid } \\
\hline Ninhydrin test & - & - & + & + \\
\hline Millon's reagent & - & - & + & + \\
\hline
\end{tabular}

\section{REFERENCES}

1. Kirtikar and Basu. Indian medicinal plants. $2^{\text {nd }}$ ed. Periodical Experts Book Agency; 1981. P. 1162-1164.

2. Prajapat N.D. A handbook of medicinal plants: a complete source book. $1^{\text {st }}$ ed. Agrobios; 2003. P. 482-483.

3. Pullaiah T. Encyclopedia of world medicinal plants Regency; 2006. P. 1830-1831.

4. Warrier P.K. Indian medicinal plant: A compendium of 500 species. $1^{\text {st }}$ ed. Orients Longman; 5, 1996. P. 73-176.

5. https://www.flowersofindia.net/catalog/slides/Creeping\%20C ucumber.html.

6. Anonymous. Quality Control Methods for Medicinal Plants. World Health Organization. Geneva. Delhi (India): A.I.T.B.S. Publishers and Distributors; 2004.

7. Anonymous. The Pharmacopoeia of India, Ministry of Health and Family Welfare, Govt. of India. New Delhi, India: Controller of Publication; 2006. P. A-74.

8. Ayurvedic Pharmacopoeia. Ministry of Health and Family Welfare. New Delhi: Controller of Publication; 2004.

9. Das C, Sahoo C, Dash S, Sahu A and Hota R, Pharmacognostical and phytochemical investigation of the stem bark of cassia tora (caesalpiniacea), International Journal of Pharmacy and Pharmaceutical Sciences, 2011; 3(5):84-88.

10. Gupta P, Vasudeva N, Sharma SK, Pharmacognostical Study and Preliminary Phytochemical Screening of the Roots of Tagetes erecta Roots, Hamdard Medicus, 2009; 52(1):153160.

11. Kokoshi J, Kokoshi R, Salma FJ, Fluorescence of powdered vegetable drugs under ultraviolet radiation, J Am Pharm Ass, 1958; $47: 715$

12. Knevel AL and Digangi FF. Jenkin's Quantitative Pharmaceutical Chemistry. $7^{\text {th }}$ ed. New Delhi (India): Blakistan Publication; 1977. P. 223-236.

13. Kohli DPS. Herbal Drug Industry. $1^{\text {st }}$ ed. New Delhi (India): Eastern Publication; 1996.

14. Kushwaha SKS, Kushwaha N, Maurya N, Rai AK, Role of markers in the standardization of herbal drugs: A review, Archives Appl. Sci. Res., 2010; 2(1),:225-229. 